\title{
Sarkopenia, Latihan, dan Kejadian Jatuh (Falls) pada Populasi Lanjut Usia
}

\author{
Sarcopenia, Exercise, and Falls Incident at Elderly Population
}

\author{
Niluh Tantri, Sri Sunarti, Gadis Nurlaila, Djoko Wahono S \\ Laboratorium Ilmu Penyakit Dalam Rumah Sakit Umum Dr. Saiful Anwar Malang
}

\begin{abstract}
ABSTRAK
Sarkopenia sangat terkait dengan penurunan fungsi dalam melakukan berbagai aktivitas penting yang pada akhirnya akan menyebabkan kerapuhan, meningkatkan risiko jatuh dan hilangnya kemandirian. Latihan diketahui merupakan salah satu modalitas terapi sarkopenia, yang juga memiliki efek protektif terhadap falls. Penelitian dilakukan untuk menemukan hubungan antara sarkopenia dan latihan dengan kejadian jatuh pada usia $>60$ tahun. Penelitian observasional dilakukan dengan pendekatan potong lintang pada populasi lanjut usia mandiri di Kabupaten dan Kota Malang sebanyak 232 subjek. Massa otot diukur mengunakan formula MAMC, kekuatan dan fungsi ekstremitas diukur menggunakan kekuatan genggaman tangan dan jarak tempuh dan kecepatan berjalan. Latihan didefinisikan sebagai senam ataupun jalan kaki minimal 120 menit perminggu. Riwayat jatuh dikatakan positif bila ada kejadian jatuh dalam 1 tahun terakhir berdasarkan anamnesis. Hasil menunjukkan 106 pasien (45,69\%) mengalami sarkopeni berdasarkan algoritme EWSGOP. Dari 106 kelompok sarkopeni, 27 subjek pernah mengalami jatuh (25,5\%). Faktor berat badan, tinggi badan, index massa tubuh, lingkar lengan atas, tricep skinfold, genggaman tangan, kecepatan berjalan dan latihan, terbukti memiliki perbedaan yang bermakna antara kelompok sarkopenia dan tidak sarkopenia $(p=0,000 ; p=0,035 ; p=0,04 ; p=0,000 ; p=0,000 ; p=0,000$; $p=0,000 ; p=0,001$ dan $p=0,031$ ). Hanya lingkar lengan atas yang didapatkan hubungan yang bermakna dengan adanya riwayat jatuh $(p=0,000)$. Didapatkan hubungan yang bermakna antara latihan dengan sarkopenia $(p=0,031)$ dengan $O R$ $1,73 \mathrm{Cl}$ 1,007-2,885, sehingga dapat dihitung probabilitas subjek yang tidak melakukan latihan akan mengalami sarkopenia sebesar 63,37\%.
\end{abstract}

Kata Kunci:Kekuatan otot, latihan, massa otot, riwayat jatuh, sarkopenia

\begin{abstract}
Sarcopenia is strongly related with functional impaired in performing important daily activities leading to brittleness, increasing falls incidence and dependency. Exercise is one of treatment modality in sarcopenia with protective effect for falls incidence. This research aimed to identify the correlation of sarcopenia, exercise and falls incidence in elderly. A cross sectional observation was performed with 232 independent elderly peoples. Muscle mass was measured based on MAMC formula, extremity strength and function was measured using hand grips walking distance and speed. Exercise is defined as gymnastic or 120 minutes-walks/week. Falls incidence was measured based on reported fall experience in the last one year. Result show that 106 patients (45,69\%) experiencing sarcopenia based on EWSGOP algorithm with 27 (25,5\%) of them reported falls incidence. Body weight $(p=0,000)$, height $(p=0,035)$, body mass index $(p=0,04)$, upper arm circle $(p<0,001)$, triceps skinfold $(p<0,001)$, hand grip $(p<0,001)$, walking speed $(p=0.001)$ and exercise $(p=0,031)$ show significant difference between sarcopenia and non sarcopenia group. Upper arm circle is the only significant determinants for falls incidence. There is a significant correlation between exercise and sarcopenia $(p=0,031 ; 0 R 1,73 \mathrm{Cl} 1,007-2,885)$ suggest that probability of sarcopenia in subject with no exercise is $63,37 \%$.
\end{abstract}

Keywords: Exercise, falls incident, muscle mass, muscle strength, sarcopenia

Jurnal Kedokteran Brawijaya, Vol. 28, No. 1, Februari 2014; Korespondensi: Sri Sunarti. Laboratorium Ilmu Penyakit Dalam, Rumah Sakit Umum Dr. Saiful Anwar Malang, Jl. Jaksa Agung Suprapto Malang(0341)357663 Email:sinartitan@rocketmail.com 


\section{PENDAHULUAN}

Kejadian jatuh (falls) dan komplikasinya merupakan salah satu problem kesehatan utama pada populasi lanjut usia. Falls sering terjadi pada populasi lanjut usia dan erat terkait dengan meningkatnya morbiditas dan mortalitas (1-4). Prevalensi falls pada lanjut usia dalam komunitas berkisar hingga 30\% dan kejadiannya meningkat hingga $40 \%$ pada usia yang sangat lanjut $(5,6)$.

Proses menua menyebabkan berbagai perubahan pada fungsi dan struktur otot. Massa otot akan menurun sejalan dengan pertambahan umur (4). Dengan massa otot yang berkurang, kekuatan dan fungsi otot juga akan menurun secara signifikan. Kondisi menurunnya massa, kekuatan dan atau fungsi otot dikenal sebagai sarkopenia $(4,5)$. Menurunnya kekuatan otot akibat penurunan massa otot, merupakan faktor prediktif yang penting dari keterbatasan fungsi dan disabilitasfisik pada usia lanjut $(4,5)$.

Berbagai studi membuktikan bahwa latihan memiliki berbagai keuntungan melalui perbaikan fungsi fisiologis pada usia lanjut. Suatu studi Cohort yang meneliti 84 subjek pria dan wanita non-diabet menemukan bahwa kadar sitokin proinflamasi Interleukin-6 (IL-6) dan CReactive Protein (CRP) pada subjek dengan aktivitas fisik aktif lebih rendah bila dibandingkan terhadap subjek dengan inaktivitas fisik, dengan IL-6 sebagai mediator utama sarkopenia (7). Studi ini bertujuan untuk mengetahui kejadian sarkopenia dan kejadian jatuh pada usia lanjut di masyarakat dan hubungan antara aktivitas fisik dengan massa dan kekuatan otot pada populasi lanjut usia. Hasil penelitian ini diharapkan dapat menegaskan pentingnya aktivitas fisik dalam mempertahankan massa dan kekuatan otot yang akan mengurangi risiko jatuh pada usia lanjut.

\section{METODE}

Survei dilakukan pada populasi lanjut usia (usia > 60 tahun) mandiri di masyarakat kabupaten dan kota Malang. Pendekatan observasional dengan consecutive sampling selama Maret hingga Mei 2013. Didapatkan 232 subjek pria dan wanita.

Pengumpulan data subjek penelitian dilakukan bulan Maret hingga Mei 2013. Data yang dikumpulkan meliputi: nama, umur, jenis kelamin, berat badan (kg), tinggi lutut $(\mathrm{m})$, tinggi badan $(\mathrm{m})$, indeks massa tubuh $(\mathrm{kg} / \mathrm{m} 2)$, lingkar lengan atas $(\mathrm{cm})$, triceps skinfold $(\mathrm{cm})$, muscle mass berdasarkan lee equation, genggaman tangan ( $\mathrm{kg})$, $4 \mathrm{~m}$ walking test, riwayat latihan, riwayat jatuh.

Sarkopenia didefinisikan sebagai penurunan massa otot disertai penurunan kekuatan otot atau performa/fungsi otot (sesuai kriteria European Working Group on Sarkopenia in Older People/ EWGSOP) (7). Massa Otot dihitung menggunakan $\mathrm{MAMC}$, dengan $\mathrm{MAMC}=\mathrm{MUAC}$ (mm)-3,14 × TSF (mm) (8).

Estimasi MAMC merupakan metode yang praktif dan sangat bermanfaat dalam assessment status nutrisi dan sarkopenia pada populasi lanjut usia. MAMC sangat sederhana, cepat dan mudah dilakukan, murah, noninvasive dan sangat bermanfaat terutama pada kondisi ketika bila DEXA dan BIA sulit dilakukan (9). Kekuatan otot dilihat dari kekuatan genggaman tangan, menggunakan dinamometer. Kekuatan otot dikatakan berkurang bila $<30 \mathrm{~kg}$ pada pria dan $<20 \mathrm{~kg}$ pada wanita, sesuai kriteria
EWGSOP (7). Penilaian performa fisik dilakukan menggunakan $4 \mathrm{~m}$ walking test, dilakukan melalui evaluasi waktu yang dibutuhkan dan kecepatan jalan biasa pasien dalam menempuh jarak $4 \mathrm{~m}$. Didefinisikan sebagai performa yang rendah bila kecepatan berjalan $<0,8 \mathrm{~m} /$ detik (10). Latihan, didefinisikan sebagai jalan kaki minimal 120 menit setiap minggu dalam satu tahun terakhir. Data mengenai latihan didapatkan dari anamnesis.

Falls, didefinisikan sebagai kehilangan keseimbangan mendadak yang menyebabkan adanya kontak anggota tubuh selain kaki dengan tanah (11). Berat badan diukur saat pasien mengunakan baju yang ringan, menggunakan timbangan berat badan digital. Tinggi badan diukur menggunakan stadiometer standar. Body mass index (BMI) didefinisikan sebagai berat badan dalam kg dibagi pangkat dua dari tingi dalam meter. Anamnesis saat pemeriksaan juga menggali informasi mengenai, diagnosis penyakit komorbid dan obat-obatan yang digunakan.

Karakteristik subjek dikategorikan berdasarkan ada tidaknya sarkopenia dan insiden jatuh. Data dianalisis untuk mendapatkan informasi deskriptif. Data kontinyu dipresentasikan sebagai rerata dan standar deviasi, perbedaan antara variabel dengan data kontinyu dilakukan menggunakan $t$ test bila data memiliki distribusi normal, sedangkan bila distribusi data tidak normal digunakan Mann-Whitney test. Untuk data katagorikal, perbedaan antara variabel dilakukan dengan uji chi-square bila syarat terpenuhi. Analisis data menggunakan SPSS 17.

\section{HASIL}

Sejumlah 106 pasien dari 232 sampel (45,69\%) mengalami sarkopeni berdasarkan algoritme EWSGOP. Dari 106 kelompok sarkopeni, 27 subjek pernah mengalami jatuh (25,5\%). Faktor berat badan, tinggi badan, index massa tubuh, lingkar lengan atas, tricep skinfold, genggaman tangan, kecepatan berjalan dan latihan, terbukti memiliki perbedaan yang bermakna antara kelompok sarkopenia dan tidak sarkopenia $(p=0,000 ; p=0,035 ; p=0,04 ; p=0,000$; $p=0,000 ; p=0,000 ; p=0,000 ; p=0,001$, dan $p=0,031$. Berdasarkan riwayat jatuh hanya lingkar lengan atas yang mempunyai hubungan bermakna dengan kejadian jatuh $(p=0,000)$.

Tabel 1. Karakteristik subjek berdasarkan sarkopenia

\begin{tabular}{|c|c|c|c|}
\hline Karakteristik & $\begin{array}{c}\text { Sarkopenia } \\
n=106\end{array}$ & $\begin{array}{c}\text { Tidak } \\
\text { Sarkopenia } \\
\mathbf{n = 1 2 6}\end{array}$ & $P$ \\
\hline $\begin{array}{l}\text { Sex } \\
\text { Laki-laki } \\
\text { Perempuan }\end{array}$ & $\begin{array}{l}38(35,80 \%) \\
68(64,2 \%)\end{array}$ & $\begin{array}{l}49(38,9 \%) \\
77(61,1 \%)\end{array}$ & $0,634^{* *}$ \\
\hline $\begin{array}{l}\text { Umur } \\
\text { (tahun) }\end{array}$ & $68,27 \pm 5,12$ & $69,02 \pm 5,32$ & $0,288^{*}$ \\
\hline $\mathrm{BB}(\mathrm{kg})$ & $51,66 \pm 12,60$ & $61,89 \pm 10,06$ & $0,000 *$ \\
\hline $\mathrm{TB}(\mathrm{m})$ & $1,55 \pm 0,07$ & $1,56 \pm 0,06$ & 0,04 \\
\hline $\mathrm{IMT}(\mathrm{kg} / \mathrm{m} 2)$ & $21,61 \pm 5,15$ & $25,29 \pm 3,97$ & 0,000 \\
\hline MUAC & $25,78 \pm 4,30$ & $25,29 \pm 3,97$ & $0,000^{*}$ \\
\hline Skinfold & $3,45 \pm 0,52$ & $2,80 \pm 1,28$ & $0,87^{*}$ \\
\hline MAMC & $13,39 \pm 1,15$ & $20,25 \pm 5,16$ & $0,000^{*}$ \\
\hline SMI & $4,51 \pm 1,27$ & $5,01 \pm 0,77$ & $0,000^{*}$ \\
\hline MMLee & $10,75 \pm 2,61$ & $12,28 \pm 2,04$ & 0,000 \\
\hline HandGrip & $18,55 \pm 5,85$ & $23,44 \pm 8,04$ & $0,000^{*}$ \\
\hline Jalan $4 m$ & $4,50 \pm 1,73$ & $3,85 \pm 1,59$ & $0,001^{*}$ \\
\hline
\end{tabular}


Tabel 1. Karakteristik subjek berdasarkan sarkopenia (lanjutan)

\begin{tabular}{|c|c|c|c|}
\hline Karakteristik & $\begin{array}{c}\text { Sarkopenia } \\
n=106\end{array}$ & $\begin{array}{c}\text { Tidak } \\
\text { Sarkopenia } \\
\text { n=126 } \\
\end{array}$ & $P$ \\
\hline $\begin{array}{l}\text { Exercise } \\
\text { (ya) } \\
\text { (tidak) }\end{array}$ & $\begin{array}{l}40(37,7 \%) \\
66(62,3 \%)\end{array}$ & $\begin{array}{l}64(50,80 \%) \\
62(49,20 \%)\end{array}$ & $0,046 * *$ \\
\hline $\begin{array}{l}\text { Falls } \\
\text { (Ya) } \\
\text { (tidak) }\end{array}$ & $\begin{array}{l}27(25,40 \%) \\
79(74,60 \%)\end{array}$ & $\begin{array}{l}24(19,00 \%) \\
102(81,00 \% \%)\end{array}$ & $0,239 * *$ \\
\hline
\end{tabular}

Keterangan: *Mann Whitney **ChiSquare

Untuk mengetahui hubungan antara sarkopenia dan latihan terhadap kejadian jatuh (falls), dilakukan pengelompokan subjek berdasarkan kejadian jatuh.

Tabel 2. Karakteristik subjek berdasarkan riwayat jatuh riwayat jatuh

\begin{tabular}{|c|c|c|c|}
\hline Karakteristik & $\begin{array}{c}\text { Ada Riwayat } \\
\text { jatuh } \\
n=51\end{array}$ & $\begin{array}{c}\text { Tidak ada } \\
\text { riwayat jatuh } \\
\mathrm{N}=182\end{array}$ & $p$ \\
\hline Sex & $21(41,20 \%)$ & $66(36,30 \%)$ & $0,518^{* *}$ \\
\hline Laki-laki & $30(58,82 \%)$ & $116(63,70 \%)$ & \\
\hline \multicolumn{4}{|l|}{ Perempuan } \\
\hline Umur & $68,06 \pm 5,53$ & $68,83 \pm 5,17$ & $0,334^{*}$ \\
\hline $\mathrm{BB}(\mathrm{kg})$ & $58,33 \pm 13,39$ & $56,84 \pm 12,09$ & $0,449 *$ \\
\hline $\mathrm{TB}(\mathrm{M})$ & $1,56 \pm 0,58$ & $1,55 \pm 0,70$ & $0,323^{*}$ \\
\hline $\mathrm{IMT}(\mathrm{kg} / \mathrm{m} 2)$ & $23,79 \pm 5,18$ & $23,56 \pm 4,81$ & 0,761 \\
\hline MUAC & $27,68 \pm 4,57$ & $27,52 \pm 4,33$ & $0,000 *$ \\
\hline Skinfold & $3,85 \pm 1,88$ & $2,89 \pm 1,33$ & $0,335^{*}$ \\
\hline MAMC & $1438 \pm 5,722$ & $17,87 \pm 5,89$ & $0,335^{*}$ \\
\hline SMI & $4,82 \pm 0,96$ & $4,77 \pm 1,08$ & $0,533^{*}$ \\
\hline MMLee & $11,83 \pm 2,61$ & $11,49 \pm 2,42$ & 0,389 \\
\hline HandGrip & $21,13 \pm 8,59$ & $21,26 \pm 7,82$ & 0,917 \\
\hline Jalan $4 m$ & $4,22 \pm 1,62$ & $4,12 \pm 1,69$ & $0,709 *$ \\
\hline Exercise & $29(56,9 \%)$ & $76(41,8 \%)$ & $0,055^{* *}$ \\
\hline $\begin{array}{l}\text { (ya) } \\
\text { (tidak) }\end{array}$ & $22(43,1 \%)$ & $106(58,2 \%)$ & \\
\hline Sarkopeni & $27(52,90 \%)$ & $79(43,60 \%)$ & $0,239 * *$ \\
\hline $\begin{array}{l}\text { (ya) } \\
\text { (Tidak) }\end{array}$ & $24(47,10 \%)$ & $102(56,40 \%)$ & \\
\hline
\end{tabular}

Keterangan: *Mann Whitney **Chi Square

Didapatkan sejumlah 51 (21,98\%) subjek memiliki riwayat jatuh dan 182 (78,45\%) subjek tanpa riwayat jatuh. Dengan uji chi square didapatkan hubungan yang bermakna antara latihan dengan sarkopenia $(p=0,031)$ dengan $\mathrm{OR} 1,73 \mathrm{Cl}$ 1,007-2,885, sehingga dapat dihitung probabilitas subjek yang tidak melakukan latihan akan mengalami sarkopenia sebesar $63,37 \%$

\section{DISKUSI}

Beberapa peneliti menemukan bahwa massa otot mencapai ukuran maksimum saatusia 30 tahun, yang selanjutnya akan menurun sebesar 3-8\% tiap dekade. Kecepatan penurunan setiap dekade setelah usia 50 tahun mencapai $12-15 \%(12,13)$. Hal ini tidak sesuai dengan hasil penelitian kami, dimana tidak ditemukan hubungan yang bermakna antara kejadian sarkopenia dengan umur subjek $(p=0,288)$. Macaluso et al telah melaporkan adanya penurunan kualitas otot, dan kemampuan untuk menghasilkan kekuatan per unit otot sejalan dengan bertambahnya usia (14).

Dua mekanisme yang terlibat dalam penurunan massa otot pada manusia, adalah: turunnya jumlah serabut otot dan hilangnya hubungan antara serabut otot. Serabut otot tipe II yang paling banyak mengalami perubahan. Sebagai akibatnya, terjadi gangguan kapasitas fungsional akibat menurunnya kekuatan dan kecepatan otot (15). Hal ini terjadi akibat rentannya serabut otot tipe II terhadap denervasi (16), defisiensi dalam ekspresi gen pada myosin tipe II (17) dan rendahnya toleransi terhadap stres oksidatif (18).

Penurunan massa serabut otot juga disebabkan oleh faktor intrinsik di miosit. Pada usia lanjut, terjadi akumulasi disfungsi mitokondria. Efek yang merugikan ini terjadi akibat akumulasi kerusakan mtDNA yang mempengaruhi laju metabolism, sintesa protein dan produksi ATP secara negatif yang akan mengakibatkan kematian serabut otot (19). Mekanisme regenerasi dan perbaikan serabut otot pada usia tua juga mengalami penurunan akibat aktivitas satelit sel yang rendah, inflamasi kronik, stres oksidatif dan respons abnormal dari micro RNA dan regulasi yang inadekuat dari proses perbaikan dari serabut otot yang mengalami kerusakan (15,20-22). Hilangnya serabut otot mengakibatkan serabut otot yang tersisa untuk melakukan kompensasi atau memperbaiki sebagian defisit yang terjadi untuk mempertahankan kapasitas optimal kekuatan otot (23).

Resistance exercise dapat menghambat dan mempengaruhi sarkopenia melalui beberapa mekanisme. Pada tingkat serabut otot, resistance exercise mentralisir berbagai mekanisme yang terlibat dalam proses terjadinya sarkopenia. Resistance exercise memicu perubahan positif pada proses inflamasi, apoptosis dan regenerasi serabut otot, serta fungsi dan anatomi serabut otot. Sehubungan dengan fungsi serabut otot, resistance exercise meningkatkan kualitas otot dengan meningkatkan jumlah sarkomer yang secara pararel akan meningkatkan kekakuan dan kemampuan tendon untuk memanjang secara elastis (young's module) $(24,25)$.

Dalam penelitian ini didapatkan hubungan yang signifikan antara latihan dan sarkopenia Odds Ratio 1,73 (Cl 1,0072,8856). Berdasarkan hasil tersebut, dapat diprediksi probalilitas subjek yang tidak melakukan latihan akan menalami sarkopenia sebesar $63,37 \%$. Studi meta analisa yang dilakukan oleh Catherine Sherrington et al menemukan bahwa latihan sebagai intervensi tunggal mampu mencegah kejadian jatuh (pooled rate ratio 0,84 , $95 \% \mathrm{Cl}$ 0,77-0,91) (26,27). Program aktivitas yang mengadung komponen latihan keseimbangan memiliki efek terbesar dalam menurunkan kejadian jatuh. Studi ini tidak menemukan hubungan yang bermakna antara latihan dengan kejadian jatuh $(p=0,058)$. Falls merupakan salah satu geriatric giants yang memiliki efek yang sangat besar terhadap morbidita dan moratlitas populasi lanjut usia. Berbagai faktor telah terbukti memiliki pengaruh yang kuat terhadap risiko jatuh, antara lain: problem lingkungan, gangguan keseimbangan, problem perubahan posisi, menurunnya kekuatan otot, gangguan gait, polifarmasi terutama obat-obatan psikoaktif, gangguan 
penglihatan, hipotensi postural dan ganguan kardiovaskuler lainnya (28).

Hasil penelitian ini mengindikasikan latihan dapat menurunkan risiko kejadin jatuh pada lansia, dengan ukuran lingkar lengan atas sebagai indikator yang berhubungan dengan kejadian jatuh. Studi ini menggunakan pendekatan

\section{DAFTAR PUSTAKA}

1. Janssen I, Heymsfield SB, and Ross R. Low Relative Skeletal Muscle Mass (Sarcopenia) in Older Persons is Associated with Functional Impairment and Physical Disability. Journal of the American Geriatrics Society. 2002; 50(5): 889-896.

2. Rosenberg IH. Sarkopenia: Origins and Clinical Relevance. The Journal of Nutrition. 1997; 127(5): 990s-991s.

3. Roubenoff R. Physical Activity, Inflammation, and Muscle Loss. Nutrition Reviews. 2007; 65(12): S208S212.

4. Doherty TJ. Aging and Sarkopenia. Journal of Applied Physiology. 2003; 95: 1717-1727.

5. Baumgartner RN, Koehler KM, Gallagher D, et al. Epidemiology of Sarcopenia among the Elderly in New Mexico. American Journal of Epidemiology. 1998; 147(8): 755-763.

6. Desrosiers J, Hébert R, Bravo G, and Rochette A. AgeRelated Changes in Upper Extremity Performance of Elderly People: A Longitudinal Study. Experimental Gerontology. 1999; 34(4): 393-405.

7. Fischer $\mathrm{CP}$, Berntsen A, Perstrup LB, Eskildsen $\mathrm{P}$, and Pedersen BK. Plasma Levels of Interleukin-6 and CReactive Protein are Associated with Physical Inactivity Independent of Obesity. Scandinavian Journal of Medicine \& Science in Sports. 2007; 17(5): 580-587.

8. Cruz-Jentoft AJ, Baeyens JP, Bauer JM, et al. European Working Group on Sarkopenia in Older People. Sarkopenia: European Consensus on Definition and Diagnosis: Report of the European Working Group on Sarkopenia in Older People. Age Ageing. 2010; 39: 412-423.

9. Francesco Landi, Rosa Liperoti, and Graziano Onder. The Usefulness of Anthropometric Measures. European Journal of Nutrition. 2013; 52:1683.

10. Rech CR, Dellagrana RA, Marucci MFN, and Petroski EL. Validity of Anthropometric Equations for the Estimation of Muscle Mass in the Elderly. Revista Brasileira de Cineantropometria \& Desempenho Humano. 2012; 14(1): 23-31.

11. Laurentani F, Russo C, Bandinelli S, et al. AgeAssociated Changes in Skeletal Muscles and Their Effect on Mobility: an Operational Diagnosis of Sarkopenia. Journal of Applied Physiology. 2003; 95(5): 1851-1860.

12. Morris JN, Fries BE, Bernabei R, et al. RAI E Home Care Assessment Manual. Washington DC: InterRAl Coporation; 1996.

13. Rolland Y, Czerwinski S, Abellan Van Kan G, et al. potong lintang, sehingga hubungan kausalitas sulit untuk dievaluasi. Untuk mendapatkan informasi yang lebih akurat tentang efek latihan dan sarkopeni terhadap kejadian jatuh pada populasi lanjut usia, pendekatan kohort prospektif dengan perlakuan akan memberikan informasi yang lebih tajam dalam evaluasi hubungan kausalitas.

Sarkopenia: Its Assessment, Etiology, Pathogenesis, Consequences and Future Perspectives. The Journal of Nutrition Health and Aging. 2008; 12(7): 433-450.

14. Macaluso A, Nimmo MA, Foster JE, Cockburn M, McMillan NC, and De Vito G. Contractile Muscle Volume and Agonist-Antagonist Coactivation Account for Differences in Torque Between Young and Older Women. Muscle \& Nerve. 2002; 25(6): 858-863.

15. Verdijk LB, Koopman R, Schaart G, Meijer K, Savelberg $\mathrm{HH}$, and Van Loon LJ. Satellite Cell Content is Specifically Reduced in Type II Skeletal Muscle Fibres in the Elderly. The American Journal of PhysiologyEndocrinology and Metabolism. 2007; 292(1): E151157.

16. Jones T, Stephenson KW, King JG, Knight KR, Marshall $\mathrm{TL}$, and Scott WB. Sarkopenia-Mechanisms and Treatments. Journal of Geriatric Physical Therapy. 2009; 32(2): 83-89.

17. Balagopal P, Schimke JC, Ades P, Adey D, and Nair KS. Age Effect on Transcript Levels and Synthesis Rate Muscle MHC and Response to Resistance Exercise. The American Journal of Physiology - Endocrinology and Metabolism. 2001; 280: E203-208.

18. Thompson LV. Age-Related Muscle Dysfunction. Experimental Gerontology. 2009; 44(1-2): 106-111.

19. Waters DL, Brooks WM, Qualls CR, and Baumgartner BN. Skeletal Muscle Mitocondrial Function and Lean Body Mass in Healthy Exercising Elderly. Mechanisms of Ageing and Development. 2003; 124(3): 301-309.

20. Dargelos E, Poussard S, Brulé C, Daury L, and Cottin P. Calcium-Dependent Proteolytic System and Muscle Dysfunctions: A Possible Role of Calpains in Sarkopenia. Biochimie. 2008; 90: 359-68.

21. Drummond M, McCarthy JJ, Fry CS, Esser K, and Rasmussen BB. Aging Differentially Affects Human Skeletal Muscle Microrna Expression at Rest and After an Anabolic Stimulus of Resistance Exercise and Essential Amino Acids. The American Journal of Physiology-Endocrinology and Metabolism. 2008; 295(6): 1333-1340.

22. Peake J, Della Gatta P, and Cameron-Smith D. Aging and Its Effects on Inflammation in Skeletal Muscle at rest and Following Exercise-Induced Muscle Injury. American Journal of Physiology. Regulatory, Integrative and Comparative Physiology. 2010; 298: R1485-1495.

23. Frontera WR, Reid KF, Phillips EM, et al. Muscle Fibre Sice and Function in Elderly Humans: A Longitudinal Study. Journal of Applied Physiology. 2008; 105(2): 637-642.

24. Narici MV and Maganaris CN. Adaptability of Elderly Human Muscles and Tendons to Increased Loading. 
Journal of Anatomy. 2006; 208(4): 433-443.

25. Reeves ND, Maganaris CN, and Narici MV. Effect of Strength Training on Human Patella Tendon Mechanical Properties of Older Individuals. The Journal of Physiology. 2003; 548(3): 971-981.

26. Beas-Jiménez JD, López-Lluch G, Sánchez-Martínez I, Muro-Jiménez A, Rodríguez-Bies E, and Navas $P$. Sarkopenia: Implications of Physical Exercise in its Pathophysiology, Prevention, and Treatment. Revista
Andaluza de Medicina delDeporte. 2011; 4(4): 158-166.

27. Sherrington C, Tiedemann A, Fairhall N, Close JC, and Lord SR. Exerciseto Prevent Falls in Older Adults: An Updated Meta-Analysis and Best Practice Recommendations. New South Wales Public Health Bulletin. 2011; 22(3-4): 78-83.

28. National Institute for Health and Clinical Excellence. The Assess-Ment and Prevention of Falls in Older People. (Online) 2004. http://www.nice.org.uk/CG21. 